NASA Technical Memorandum 107245

\title{
Performance of a Spacecraft DC-DC Converter Breadboard Modified for Low Temperature Operation
}

Scott S. Gerber

NYMA, Inc.

Brook Park, Ohio

Richard Patterson and Biswajit Ray

Lewis Research Center

Cleveland, Ohio

Chris Stell

Jet Propulsion Laboratory

Pasadena, California

Prepared for the

31st Intersociety Energy Conversion Engineering Conference cosponsored by IEEE, AIChE, ANS, SAE, AIAA, and ASME Washington, DC, August 11-16, 1996

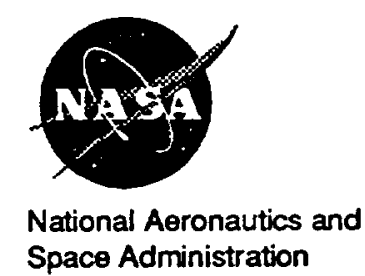




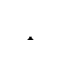




\title{
PERFORMANCE OF A SPACECRAFT DC-DC CONVERTER BREADBOARD MODIFIED FOR LOW TEMPERATURE OPERATION
}

\author{
Scott S. Gerber \\ NYMA, Inc. \\ NASA Lewis Research Center Group \\ Cleveland, $\mathrm{OH} 44135$ \\ (216) 433-8059 \\ Richard Patterson and Biswajit Ray* \\ NASA Lewis Research Center \\ Cleveland, $\mathrm{OH} 44135$ \\ (216) 433-8166 \\ Chris Stell \\ Jet Propulsion Laboratory \\ California Institute of Technology \\ Pasadena, CA 91109
}

(819) 354-5987

\begin{abstract}
A $10 \mathrm{~W} 30 \mathrm{~V} / 5.0 \mathrm{~V}$ push-pull de-dc converter breadboard, designed by the Jet Propulsion Laboratory (JPL) with a $+50^{\circ} \mathrm{C}$ to $+5^{\circ} \mathrm{C}$ operating range for the Cassini space probe, was characterized for lower operating temperatures. The breadboard converter which failed to operate for temperatures below $-125^{\circ} \mathrm{C}$ was then modified to operate at temperatures approaching that of liquid nitrogen (LN2). Associated with this low operating temperature range $\left(>-196^{\circ} \mathrm{C}\right.$ ) was a variety of performance problems such as significant change in output voltage, converter switching instability, and failure to restart at temperatures below $-154^{\circ} \mathrm{C}$. An investigation into these problems yielded additional modifications to the converter which improved low temperature performance even further.
\end{abstract}

\section{INTRODUCTION}

In 1997 the Cassini Interplanetary Probe will be launched to explore the rings of Saturn and Titan, a moon of Saturn. The average temperature of an unheated space probe near Saturn would be about $90 \mathrm{~K}$ or $-183^{\circ} \mathrm{C}$. The Cassini $\mathrm{dc}-\mathrm{dc}$ converter tested supplies power to what is called a Remote Engineering Unit (REU), which performs a variety of command and data transfer functions.

Typically, in deep space probes, RHUs (Radioisotope Heating Units) are used to keep the spacecraft electronics near room temperature (about $25^{\circ} \mathrm{C}$ ). However, there are advantages to operating the electronics at the cryogenic temperatures of deep space. They include eliminating or reducing thermal system requirements such as thermal shutters and the need for RHUs, which can create overheating at launch time. In addition, the performance of certain semiconductor devices improve with decreasing temperature down to LN2 $\left(-196^{\circ} \mathrm{C}\right)$ due to improved electrical, electronic and thermal properties (Dean, 1991, Ray et al., 1995a). At low temperatures, majority carrier devices, in particular, demonstrate reduced leakage current and reduced latch-up susceptibility. Also, majority carrier devices show higher speed resulting from increased carrier mobility and saturation velocity (Dean, 1991, Kirschman, 1985, Ray et al., 1995a). An example is the power Mosfet which also has lower conduction losses at low temperature due to the reduction in drain-to-source resistance resulting from increased carrier mobility (Mueller, 1989, Ray et al., 1995a,b).

The objective of this work was to determine the lowest operating temperature of a modern NASA dc-dc converter breadboard and if nocessary modify the converter to obtain operation down to $-196^{\circ} \mathrm{C}$. A dc-de converter designed by JPL for the Cassini space probe was the converter chosen. This work was divided into three phases. The initial phase was to test the Cassini converter breadboard as designed by JPL and to determine its low temperature performance. The second phase was to make a few simple modifications and if possible extend its operation to $-185^{\circ} \mathrm{C}$ (the lower limit of test chamber) and to observe the converter performance at low temperature. The third phase consisted of making additional modifications to improve overall performance and to characterize operation over the wide range from room temperature to $-196^{\circ} \mathrm{C}$. An LN2 bath was used in the third phase to reach $-196^{\circ} \mathrm{C}$. Because this low temperature work started late in the design cycle, it was too late to impact design for the Cassini mission. The intent of the work was to test and modify a modem converter for other future deep space missions.

\section{JPL CASSINI DC-DC CONVERTER}

The breadboard converter from JPL is the Cassini REU power conditioning unit. The $30 \mathrm{~V} / 5.0 \mathrm{~V}$ push-pull dc-dc converter is shown in block diagram form in Figure 1. Table 1 lists some of the requirements for the converter. Converter control functions are performed by a 1846 PWM Current-Mode Controller as shown in Figure 1. This controller utilizes both current feedback

*National Research Council-NASA Research Associate at Lewis Research Center 
and voltage error feedbeck. Primary current is sensed through two current transformers CT1 and CT2 (Figures 1 and 7a), and the sensed current is fedback to the controller where slope compensation is addod. The error feodback circuitry (Figures 1 and 8a) consists of the $5 \mathrm{~V}$ output sense being compared to a voltage reference and then transformer-coupled back to the 1846 IC. The feedback is transformer-coupled to maintain the 1MQ isolation requirement between input and output grounds (Table 1). Power for the 1846 controller is supplied by the circuit shown in Figure 2a. Extensive input and output filtering are used to produce an ultra-low noise converter.

\section{EXPERIMENTAL RESULTS AND DISCUSSION}

The first phase of this work consisted of observing the operation of the JPL Cassini converter from room temperature $\left(25^{\circ} \mathrm{C}\right)$ to its lowest operating temperature. Texting was performed in a liquid nitrogen cooled chamber manufactured by SUN Systems. The lowest temperature achievable by the SUN System was $-185^{\circ} \mathrm{C}$. The variables observed consistod of drain-to-source voltages of the two main switching Mosfets, the voltage ripple of the internal de bus, the sync sigmal into the controller, and the output voltage. Figure 3 shows the room temperature switching waveforms for an output load current of 0.5A. Figures 4 and 5 show the erratic switching behavior observed at $-115^{\circ} \mathrm{C}$ and $-123^{\circ} \mathrm{C}$, respoctively. At $-123^{\circ} \mathrm{C}$, with the sync signal still present, the converter stopped running and would not restart until the temperature rose to $-110^{\circ} \mathrm{C}$. The initial test demonstrated good circuit behavior down to $-110^{\circ} \mathrm{C}$, which is beyond the required operating temperature range of $+50^{\circ} \mathrm{C}$ to $+5^{\circ} \mathrm{C}$.

The second phase of this work was to extend the operating range of the converter down to temperatures approaching $-185^{\circ} \mathrm{C}$. To achieve this objoctive would roquire component replacement and circuit modification. The first step was to replace the existing bipolar type 1846 IC controller with a CMOS 1846 IC controller by TelCom. Previous experience and work (Ray et al., 1995a,b) have shown that CMOS integrated circuits have improved performances at low temperature. The CMOS 1846 IC required an additional input buffer for the sync signal. Two TelCom CMOS TC4429 inverting driver chips in series were used as shown in Figure 1. Testing of the modifiod breadboard demonstrated operation down to $-185^{\circ} \mathrm{C}$. However, several problems were observed in the converter's behavior. First, it was noted that at temperatures betwoen $-111^{\circ} \mathrm{C}$ and $-125^{\circ} \mathrm{C}$ erratic switching behavior was observed as in the initial phase. This behavior was somewhat load dependent; the higher the load the lower the temperature at which erratic switching occurred. Secondly, it was observed that the output voltage changed dramatically at about $-122^{\circ} \mathrm{C}$. The output voltage jumped from within its normal operating range $5 \mathrm{~V} \pm 5 \%$ to beyond its maximum limit of $6 \mathrm{~V}$ as shown in Figure 6a. Finally, the converter would stop functioning when a heavy load was applied at temperatures below $-157^{\circ} \mathrm{C}$. In addition, the converter failed to restart for temperatures below $-154^{\circ} \mathrm{C}$.

There was a concem, that the output voltage ripple would increase beyond its $50 \mathrm{mV}$ limit as temperature decreased. As Figure $6 \mathrm{~b}$ shows, the converter remained within this limit for a load current equal to 0.1A. However, at the higher bad current of $1.1 \mathrm{~A}$, this limit was exceoded around $-125^{\circ} \mathrm{C}$ due to the converter instability. The internal de bus voltage ripple was more significantly affected by temperature as shown by Figure 6c. This can be attributed to the general purpose ceramic capacitors used in the input filter.

In the third phase, solutions to the problems discovered in the second phase were investigated, and additional modifications to the converter were made to improve its performance. The first task was to determine why the converter would quit under heavy loading and why it would not restart for temperatures below $-154^{\circ} \mathrm{C}$. Both these problems were found to be related to the same section of circuitry on the converter controls as shown in detail in Figure 2a. Under normal operation, power for the 1846 control IC is supplied by a secondary winding of the main transformer. When input voltage is first applied, there is no switching action and hence no power out of the transformer to drive the 1846 IC to start the switching action. A bipolar LM117H linear regulator fed by the $30 \mathrm{~V}$ input voltage exists to power the 1846 IC during this time in order to start the switching action. The LM117H is also there to supply power if the output becomes sufficiently loaded wich that the output transformer secondary voltage drops below the undervoltage shutdown limit of the 1846 IC. The LM117H fails to operate below $-154^{\circ} \mathrm{C}$, hence the converter will not restart or be able to handle a heavy load that drops the 1846 IC source voltage below its shutdown limit. A solution to this problem was to replece the LM117H with a zener diode of the appropriate voltage fod from the $30 \mathrm{~V}$ as shown in Figure 2b. A zener diode in this voltage range continues to work at liquid nitrogen temperature with a loss of about $20 \%$ of its zener voltage from rocm temperature. The main problem with using a zener is the appropriate impedance matching with the transformer cutput supply.

The dramatic change in output voltage and the instability problems were addreseed by investigating the two feedback loops in the control circuitry. The current feedback bop (Figure 7a) contains a 2 N2222 bipolar transistor which affers from significant loss in gain at low temperature. It was determined that this circuitry could be modified as shown in Figure 7b. Howeve, this change produced minor improvement in stability and no noticeable effect on output voltage drift. The voltage foedback bop (Figure 8a) proved to be mare complicatod. This circuit contains a procision voltage reference, an operational amplifier comparator driving a 2N2222, and an isolation transformer. The $5 \mathrm{~V}$ sense is compered to the reference, and if the output drops below a specified voltage, the 2 N2222 is driven ON, which loads one of two secondaries of the isolation transformer. When the voltage drops on this secondary, the other secondary voltage also drops. Changes in this secondary are sensed by the controller which adjusts the duty cycle appropriately to maintain the $5 \mathrm{~V}$ output. An investigation into this circuitry determined that better performance could be achieved for bw temperatare by modifying the circuit as shown in Figure 8b. Modifications include replecing the 2N2222 with a Mosfet as well as replacing the operational amplifier with a CMOS equivalent. The CMOS operational amplifier required a higher supply voltage than $5 \mathrm{~V}$ in order to overcome the gatethreshold voltage of the Mosfet. As a result, an external TV 
supply was used. The precision voltage reference was tested separately. For temperatures below $-150^{\circ} \mathrm{C}$, the original device showed significant instability. As a result, it was replaced by a zener voltage regulator diode (1N4680). This zener showed a small and stable drift in voltage.

Several capacitors were replaced with NPO ceramic versions (some were not as high in value). The internal de bus voltage ripple was reduced with the addition of a 5uF film capacitor which performs better at low temperature than the ceramic (non-NPO) used on the breadboard. The low temperature performance of the converter after these changes was significantly improved. Voltage regulation was maintained within specifications as shown in Figure 9a, which is a significant improvement over the second phase results shown in Figure $6 \mathrm{a}$. The output voltage ripple stayed within specifications down to about $-175^{\circ} \mathrm{C}$ as shown in Figure $9 \mathrm{~b}$. The de bus ripple was also significantly improved as seen in Figure 9c. Figure 10 shows the converter operation at room temperature, $-150^{\circ} \mathrm{C}$ and $185^{\circ} \mathrm{C}$. Rocm temperature operation was unaffected by the changes, and operation at $-150^{\circ} \mathrm{C}$ is only slightly different from room temperature. This difference is more evident at light loads and during the switch off-times. The converter did show some slight switching instability for temperatures below $-162^{\circ} \mathrm{C}$, which can be seen in the $-185^{\circ} \mathrm{C}$ switching waveform of Figure 10. A LN2 bath was used to test the converter at $-196^{\circ} \mathrm{C}$. Operation at this temperature was similar to $-185^{\circ} \mathrm{C}$ operation with a slight degradation in output voltage ripple, which was over the $50 \mathrm{mV}$ specification. Elimination of the switching instability would improve the output voltage ripple. In addition, more output filter capacitance could be used, or a film capacitor with lower ESR could be substituted.

\section{CONCLUSION}

A JPL 10W 30V/5.0V push-pull dc-dc converter breadboard, designed with a $+50^{\circ} \mathrm{C}$ to $+5^{\circ} \mathrm{C}$ operating range for the Cassini space probe, was characterized for lower operating temperatures. The original breadboard converter which failed to operate for temperatures below $-125^{\circ} \mathrm{C}$ was modified to operate at temperatures approaching that of liquid nitrogen. Associated with this low operating temperature range $\left(>-185^{\circ} \mathrm{C}\right)$ was a variety of performance problems such as significant change in output voltage, converter switching instability, and failure to restart at temperatures below $-154^{\circ} \mathrm{C}$. An investigation into these problems yielded additional modifications to the converter which significantly improved the performance associated with low temperature operation. These modifications included replacing parts that were not expected to perform well at low temperature with temperature-stable equivalent parts which would perform better. As an example, the bipolar PWM chip was replaced with a CMOS equivalent PWM chip. Sometimes extra circuits were added for better interfacing to the existing circuitry. These simple changes provided significant improvement in very low temperature operation, and good room temperature operation was still maintained. Not all specifications of the converter's operation were investigated at low temperature. Other tests could include EMI, reliability, transient testing, and interfacing to other boards.

\section{REFERENCES}

Dean, M. J., 1991, 'Low temperature microelectronics: opportunities and challenges," Proc. Symp. Low Temperature Electronic Device Operation, ed. Foty, D., Saks, N., Raider, S. and Oleszek, G., Vol. 91-14, pp. 25-37, The Electrochemical Society.

Kirschman, R. K., 1985, "Cold electronics: an overview," Cryogenics, Vol. 25, No. 3, pp.115-122, March.

Mueller, O., 1989, "On-resistance, thermal resistance and reverse recovery time of power MOSFETs at 77K," Cryogenics, pp. 1006-1014, Vol. 29, October.

Ray, B., Gerber, S. S., Patterson, R. L. and Myers, I. T., 1995a, "Power Control Electronics for Cryogenic Instrumentation," Advances in Inst. and Control, Vol. 50, Part 1, Int. Soc. for Meas. and Control, pp. 131-139.

Ray, B., Gerber, S. S., Patterson, R. L. and Myers, I. T., 1995b, "77K Operation of a Multi-Resonant Power Converter," IEEE-PESC Record, pp. 55-60, June.

National Research Council Fellow on leave form the University of Puerto Rico-Mayaguez Campus.

\section{ACKNOWLEDGMENTS}

This work was supported by NASA Lewis Research Center, Contract \#NAS3-27186, Task Order \#5430-05, "Electronics for Cold Operating Temperatures".

\begin{tabular}{|lc|}
\hline Minimum Input Voltage & \multicolumn{1}{|c|}{$22 \mathrm{Vdc}$} \\
\hline Output Voltage Setting & $+5 \mathrm{~V}$ \\
\hline Voltage Regulation & $5 \%$ \\
\hline Maximum Ripple Voltage & $50 \mathrm{mV} \mathrm{pk}-\mathrm{pk}$ \\
\hline No-Load Maximum Voltage & $5.5 \mathrm{~V}$ \\
\hline Overvoltage Limit & $6.0 \mathrm{~V}$ \\
\hline Maximum Load Current & $1.1 \mathrm{~A}$ \\
\hline Maximum Input Voltage & $35.25 \mathrm{Vdc}$ \\
\hline Nominal Load Current & $0.09 \mathrm{~A}$ \\
\hline Operating Temperature & +5 to $+50^{\circ} \mathrm{C}$ \\
\hline Input to Output Isolation & $>1 \mathrm{M} \Omega$ \\
\hline
\end{tabular}

TABLE 1: JPL Cassini REU DC-DC Converter Requirements (Partial List). 


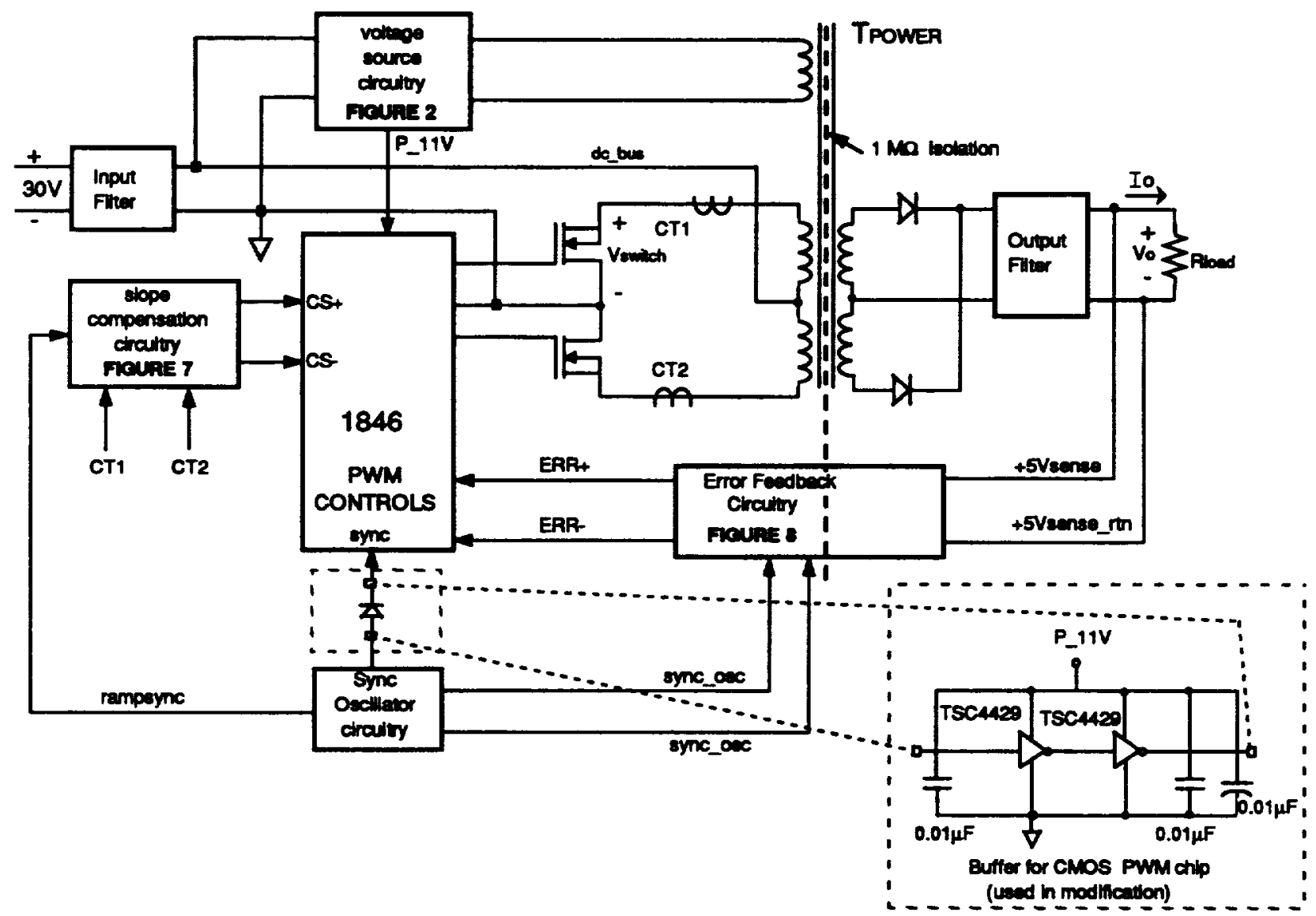

FIGUAE 1: Block diagram of the JPL Cassini dc-dc breacboard converter.

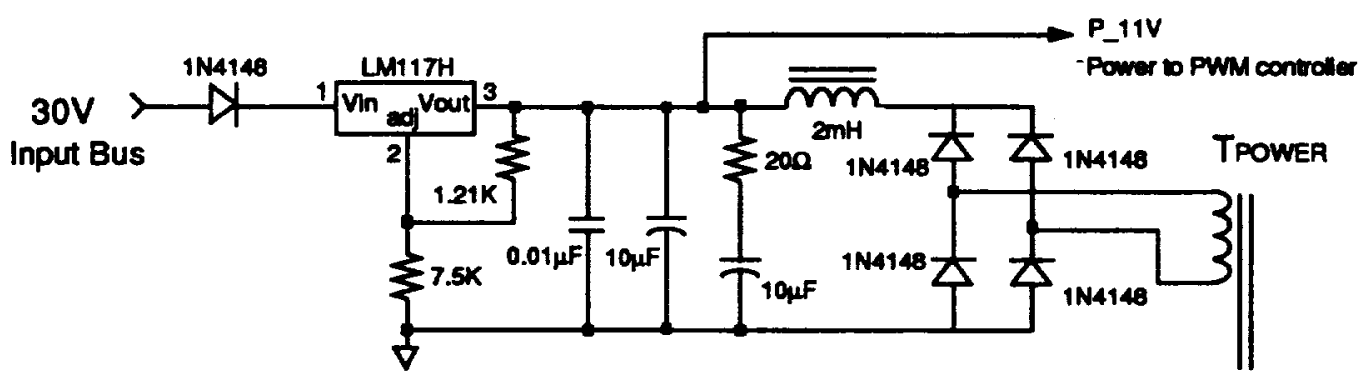

FIGURE 2a: Original Voltage source circuitry for controller power.

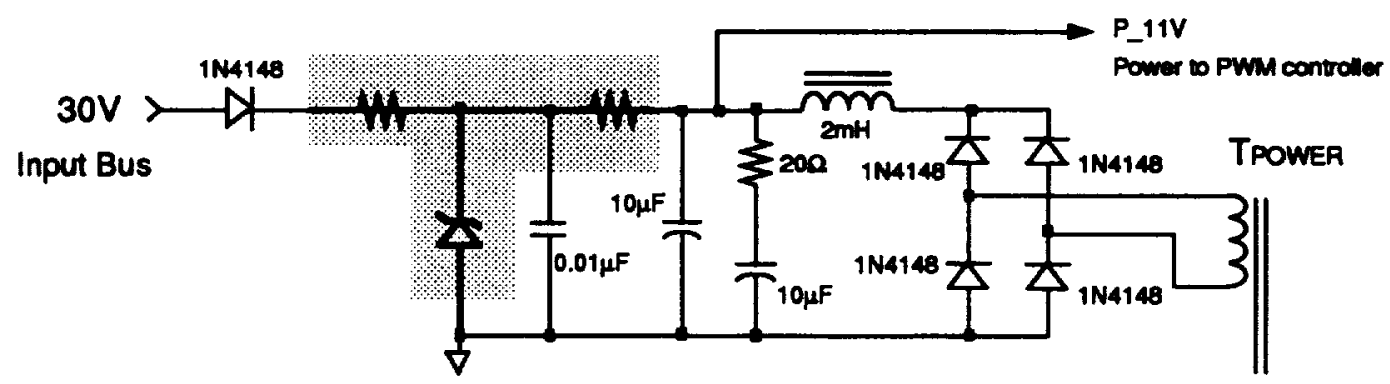

FIGURE 2b: Modified voltage source circuitry for controller power. 


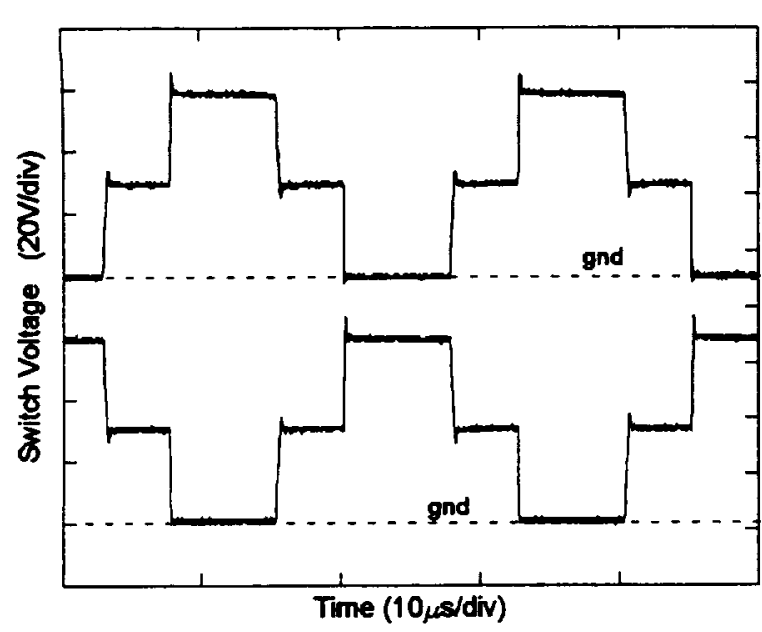

Figure 3: Room temperature switching waveforms for unmodified JPL Cassini converter.

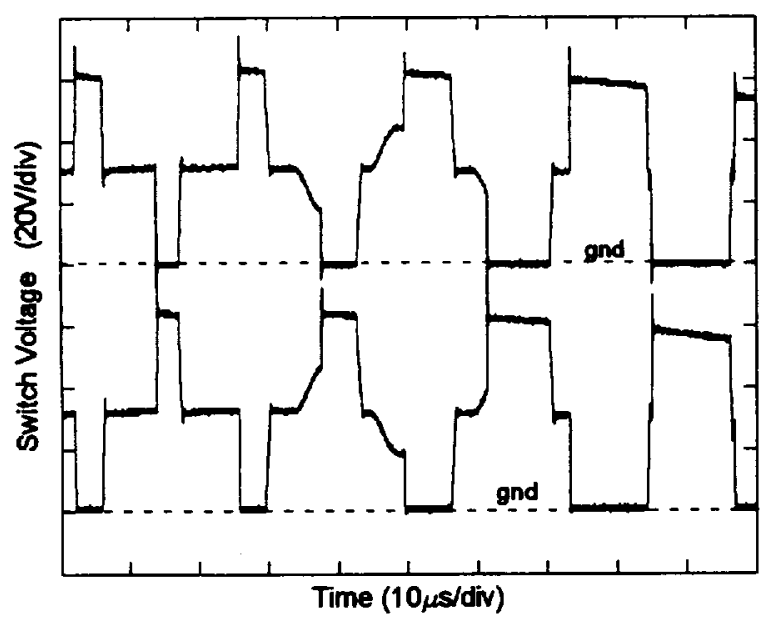

Figure 4: Switching waveform at $-115^{\circ} \mathrm{C}$ for unmodified JPL Cassini converter.

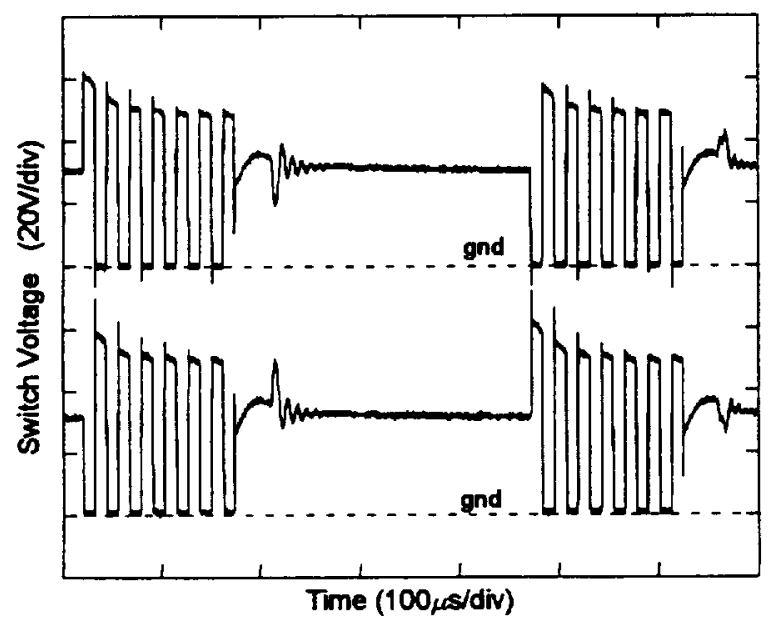

Figure 5: Switching waveforms at $-123^{\circ} \mathrm{C}$ for unmodified JPL Cassini converter.
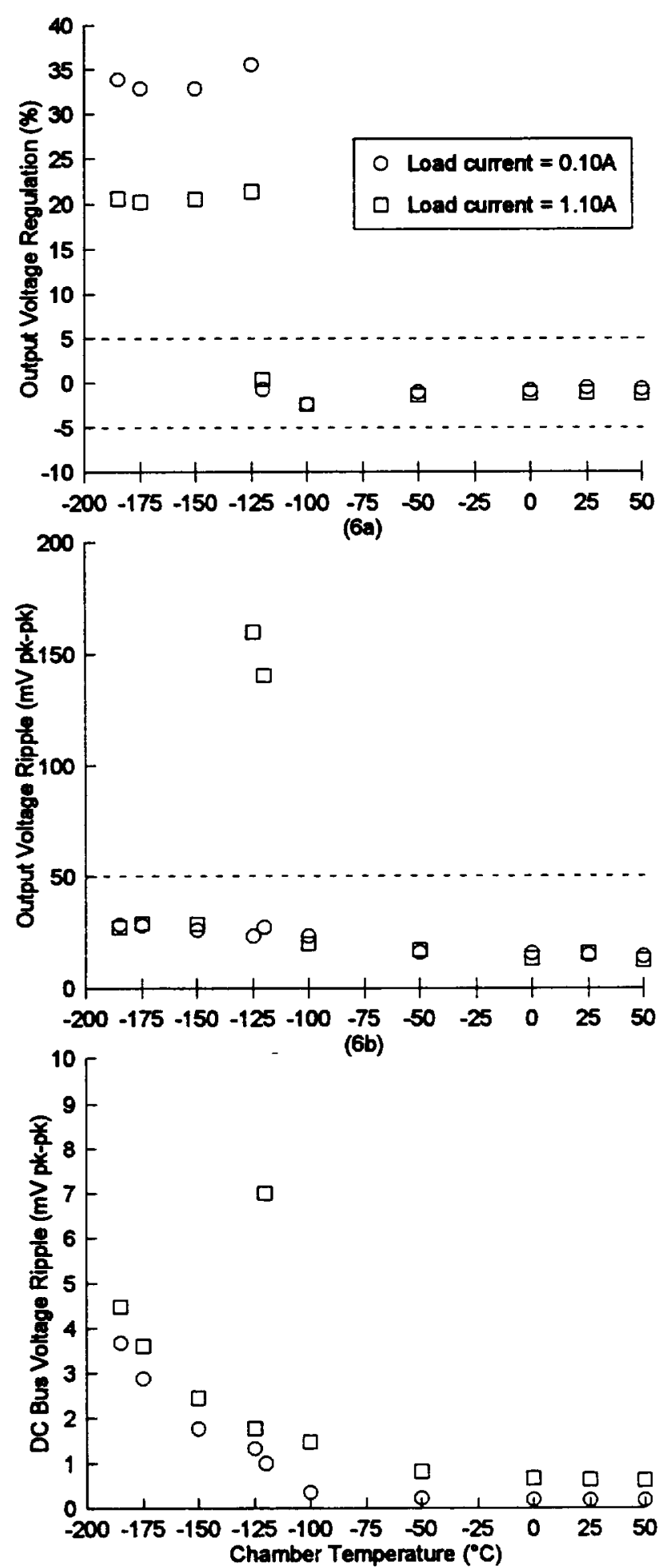

(6c)

Figure 6: Results of the second phase testing of the Cassini converter. 


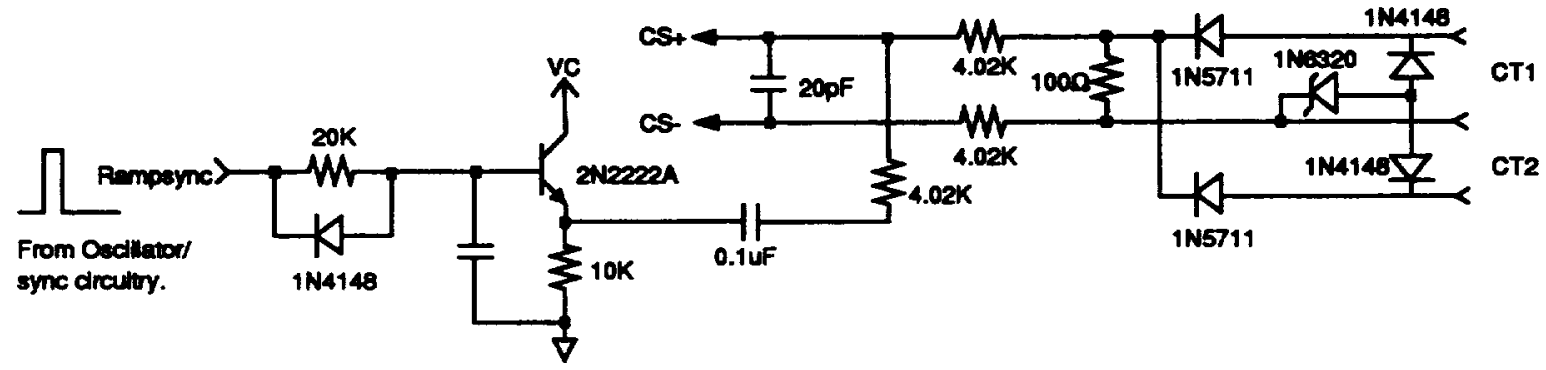

FIGURE 7a: Original slope compensation circuitry for current feedback.

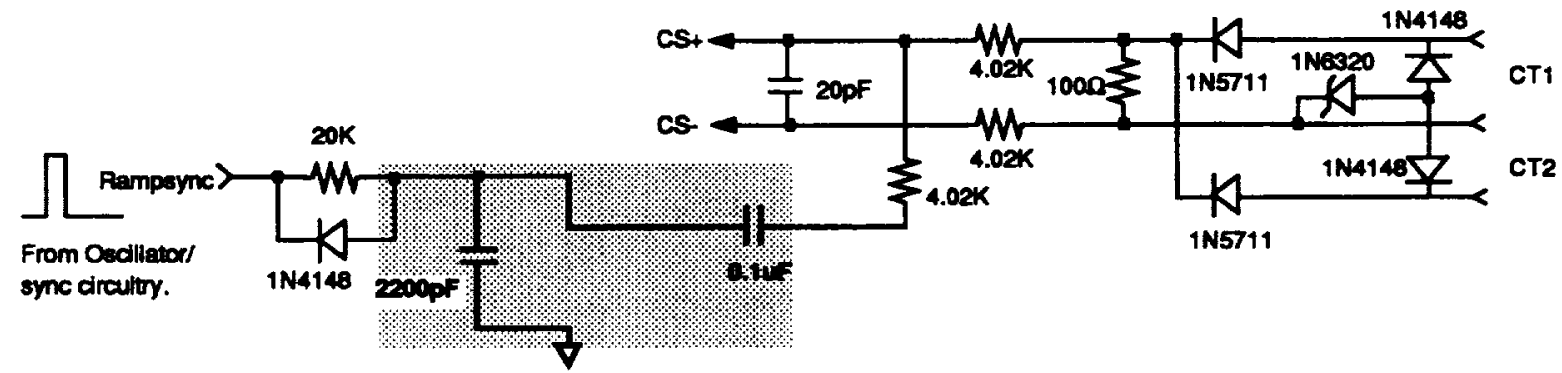

FIGURE 7b: Modified slope compensation circuitry for current feedback.

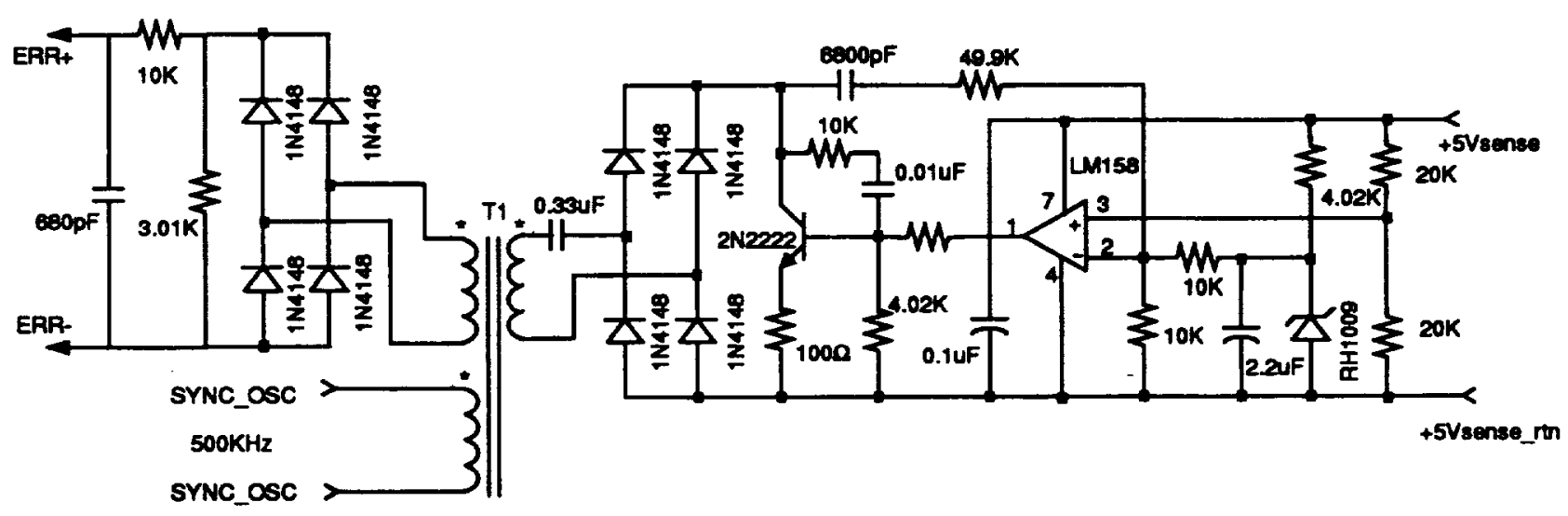

FIGUAE 8a: Original error feedback circuit for Cassini breadboard.

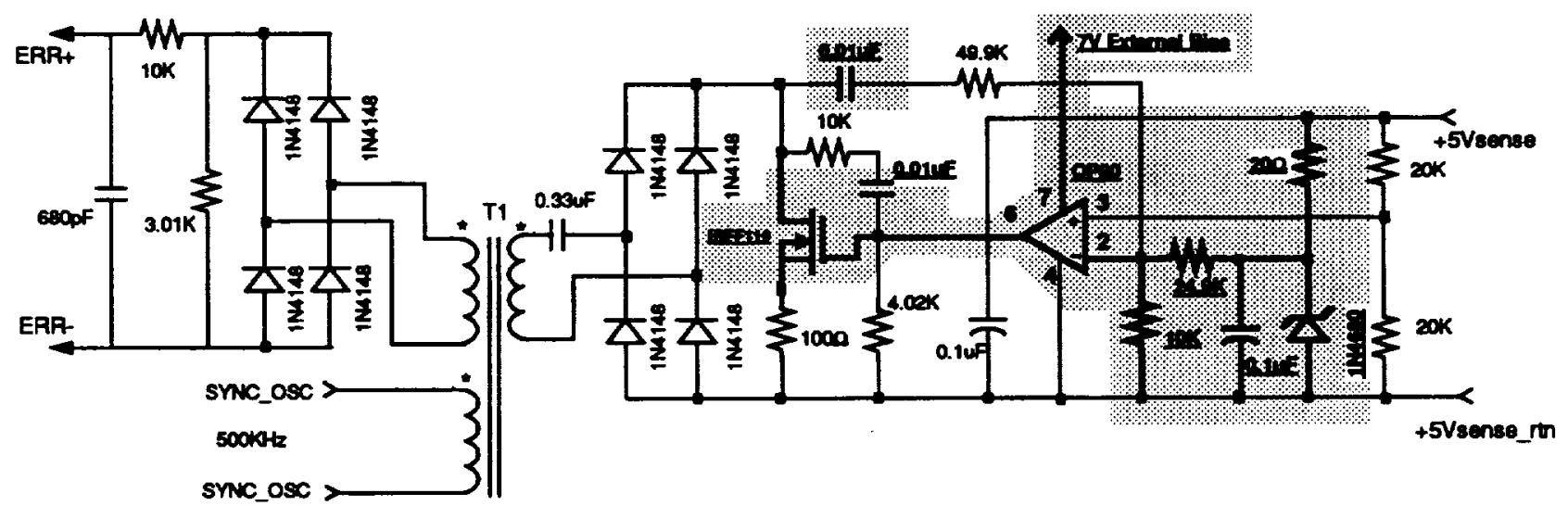

FIGURE 8b: Modified error feedback circuit for Cassini breadboard. 

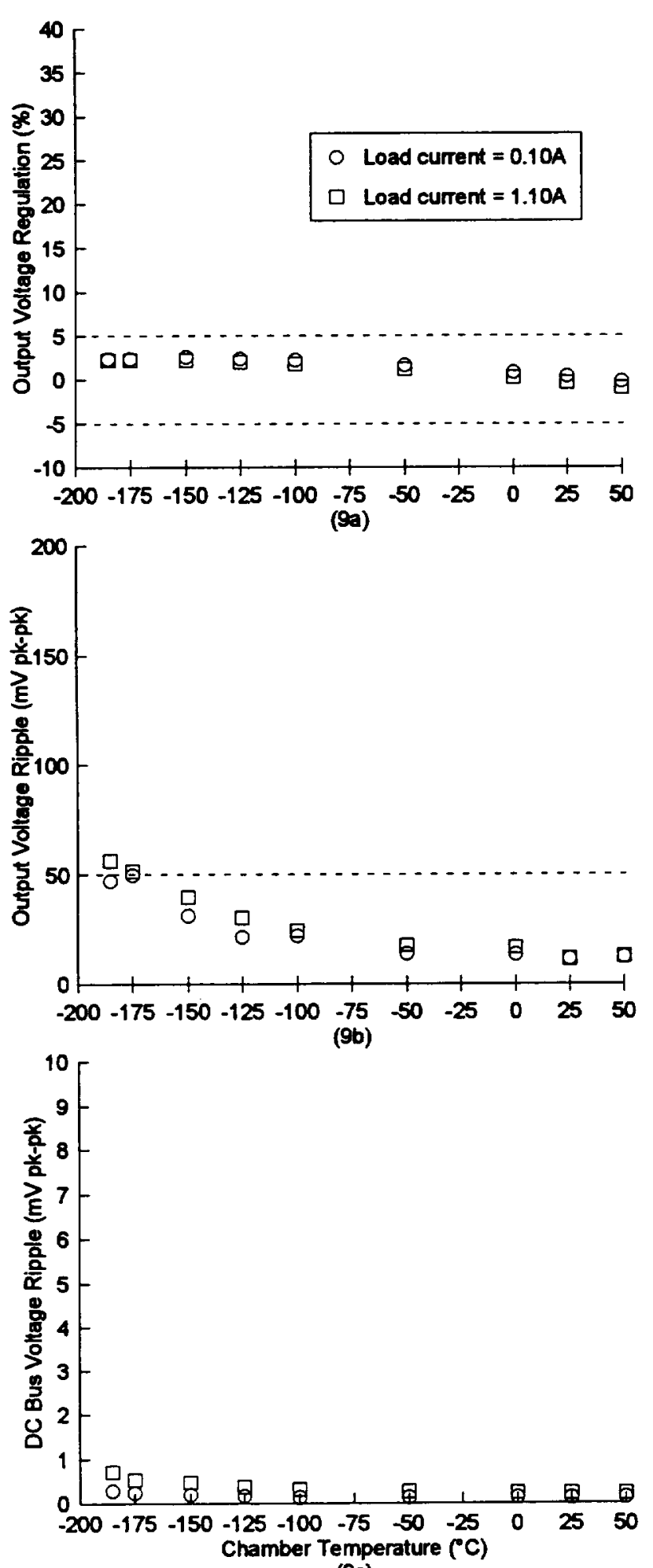

(sc)

Figure 9: Results of the third phase testing of the Cassini converter.
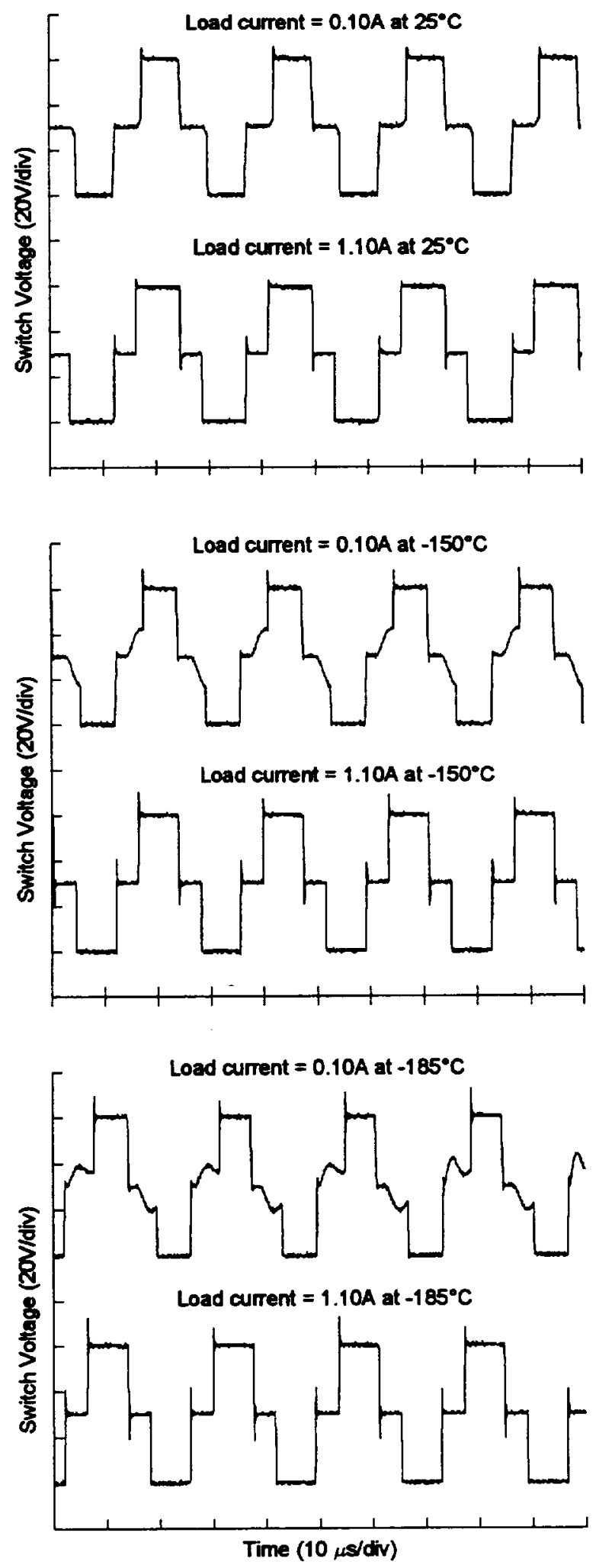

Figure 10: Switching waveforms from the third phase testing of the Cassini converter. 


\begin{tabular}{|c|c|c|c|c|}
\hline \multicolumn{3}{|c|}{ REPORT DOCUMENTATION PAGE } & & $\begin{array}{l}\text { Form Approved } \\
\text { OMB No. 0704-0188 }\end{array}$ \\
\hline \multicolumn{5}{|c|}{ 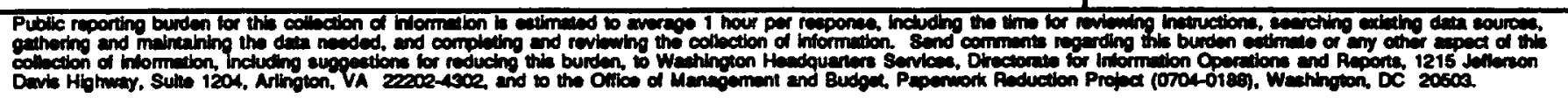 } \\
\hline 1. AGENCY USE ONLY (Leave blank) & $\begin{array}{r}2 \text { RIEPOAT DATE } \\
\text { June } 1996\end{array}$ & \multicolumn{3}{|c|}{$\begin{array}{l}\text { 3. REPOAT TYPE AND DATES COVERIGD } \\
\text { Technical Memorandum }\end{array}$} \\
\hline \multicolumn{4}{|c|}{$\begin{array}{l}\text { 4. TILE AND SUBTILE } \\
\text { Performance of a Spacecraft DC-DC Converter Breadboard Modified for } \\
\text { Low Temperature Operation }\end{array}$} & \\
\hline \multicolumn{3}{|c|}{$\begin{array}{l}\text { 6. AUTHOR(S) } \\
\text { Scott S. Gerber, Richard Patterson, Biswajit Ray, and Chris Stell }\end{array}$} & & \\
\hline \multicolumn{3}{|c|}{$\begin{array}{l}\text { 7. PERFOAIING ORGANIZATION MAME(S) AND ADDRESS(ES) } \\
\text { National Aeronautics and Space Administration } \\
\text { Lewis Research Center } \\
\text { Cleveland, Ohio } 44135-3191\end{array}$} & \multicolumn{2}{|c|}{$\begin{array}{l}\text { 8. PERFORMIMG ORGANAZATION } \\
\text { REPOFT MUMBER } \\
\text { E-10294 }\end{array}$} \\
\hline \multicolumn{3}{|c|}{ 9. SPONSORINGNONITORING AGEMCY MAME(S) AND ADDRESS(ES) } & \multicolumn{2}{|c|}{$\begin{array}{l}\text { 10. SPONSORAMGMNONITOPING } \\
\text { AGENCY REPORT MUIUER }\end{array}$} \\
\hline \multicolumn{5}{|c|}{$\begin{array}{l}\text { Prepared for the 31st Intersociety Energy Conversion Engineering Conference cosponsored by IEEE, AIChE, ANS, SAE, } \\
\text { AIAA, and ASME, Washington, DC, August 11-16, 1996. Scou S. Gerber, NYMA, Inc., } 2001 \text { Aerospace Parkway, Brook } \\
\text { Park, Ohio } 44142 \text { (work funded under NASA Contract NAS3-27186); Richard Patterson, NASA Lewis Research Center, } \\
\text { Biswajit Ray, National Research Counci-NASA Research Associate at Lewis Research Center, Chris Stell, Jet Propul- } \\
\text { sion Laboratory, California Institute of Technology, Pasadena, California } 91109 \text {. Responsible person, Richard Patterson, } \\
\text { organization code 5430, (216) 433-8166. }\end{array}$} \\
\hline \multicolumn{4}{|c|}{$\begin{array}{l}\text { 12a. DISTRIBUTIONAVALABILTY STATENENT } \\
\text { Unclassified - Unlimited } \\
\text { Subject Categories } 20 \text { and } 33 \\
\text { This publication is available from the NASA Center for AeroSpace Information, (301) 621-0390. }\end{array}$} & TRIBUTION CODE \\
\hline \multicolumn{5}{|c|}{$\begin{array}{l}\text { A } 10 \mathrm{~W} 30 \mathrm{~V} / 5.0 \mathrm{~V} \text { push-pull dc-dc converter breadboand, designed by the Jet Propulsion Laboratory (JPL) with a }+50^{\circ} \mathrm{C} \text { to } \\
+5^{\circ} \mathrm{C} \text { operating range for the Cassini space probe, was characterized for lower operating temperatures. The breadboard } \\
\text { converter which failed to operate for temperatures below }-125^{\circ} \mathrm{C} \text { was then modified to operate at temperatures approach- } \\
\left.\text { ing that of liquid nitrogen (LN2). Associated with this low operating temperature range ( }>-196^{\circ} \mathrm{C}\right) \text { was a variety of } \\
\text { performance problems such as significant change in output voltage, converter switching instability, and failure to restart at } \\
\text { temperatures below }-154^{\circ} \mathrm{C} \text {. An investigation into these problems yielded additional modifications to the converter which } \\
\text { improved low temperature performance even further. }\end{array}$} \\
\hline \multirow{2}{*}{\multicolumn{4}{|c|}{$\begin{array}{l}\text { 14. SUBJECT TERMS } \\
\text { Low temperature; DC/DC; Spacecraft; Power converter; Power supply }\end{array}$}} & $\begin{array}{c}\text { 15. MUMBER OF PAGES } \\
9\end{array}$ \\
\hline & & & & $\begin{array}{l}\text { 16. PRICE CODE } \\
\text { A02 }\end{array}$ \\
\hline $\begin{array}{l}\text { 17. SECUATTY CLASSIFICATION } \\
\text { OF REPORT } \\
\text { Unclassified }\end{array}$ & $\begin{array}{l}\text { 18. SECUPITY CLASSIFICATION } \\
\text { OF THIS PAGE } \\
\text { Unclassified }\end{array}$ & $\begin{array}{l}\text { 19. SEC } \\
\text { OF }\end{array}$ & & 20. LIMATATION OF ABSTRACT \\
\hline
\end{tabular}




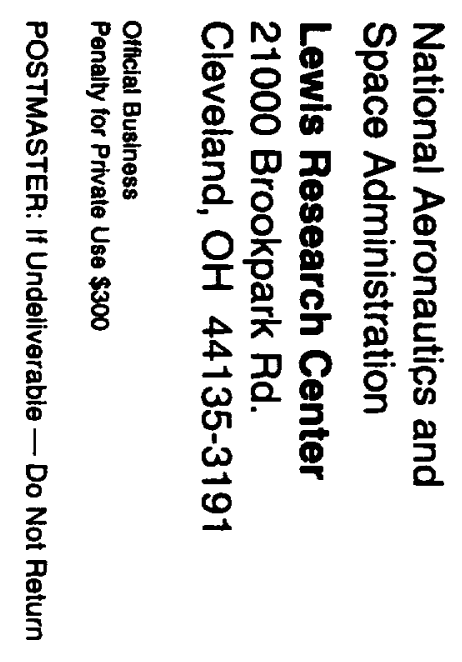

